\title{
Crawling up the value chain: domestic institutions and non-traditional foreign direct investment in Brazil, 1990-2010*
}

\author{
PATRICK J. W. EGAN**
}

RESUMO: O Brasil atraíu relativamente pouca inovação intensiva e orientada para a exportação de investimento estrangeiro durante o período de liberalização, de 1990 a 2010, especialmente em comparação com concorrentes como a China e Índia. Adotando uma perspectiva institucionalista, defendo que os perfis multinacionais de empresa de investimentos pode ser parcialmente explicado pelas características de políticas de promoção de investimento e burocracias encarregados de sua implementação. As políticas de IDE brasileiras eram passivas e não discriminatórias na segunda metade da década de 1990, mas tornou-se mais seletiva no governo Lula. Esforços de promoção de investimentos têm sido muitas vezes minado por instituições fracamente coordenadas e inconsistentes. Este artigo destaca a necessidade de políticas ativas e discriminatórias de promoção de investimento se forem realizados benefícios de IDE não-tradicionais

PALAVRAS-CHAVE: Empresas multinacionais; investimento estrangeiro direto; Brasil; política industrial; promoção de investimentos; inovação; promoção das exportações.

ABSTRACT: Brazil attracted relatively little innovation-intensive and export-oriented foreign investment during the liberalization period of 1990 to 2010, especially compared with competitors such as China and India. Adopting an institutionalist perspective, I argue that multinational firm investment profiles can be partly explained by the characteristics of investment promotion policies and bureaucracies charged with their implementation. Brazil's FDI policies were passive and non-discriminating in the second half of the 1990s, but became more selective under Lula. Investment promotion efforts have often been undercut by weakly coordinated and inconsistent institutions. The paper highlights the need for active, discriminating investment promotion policies if benefits from non-traditional FDI are to be realized.

KEYWORDS: Multinational enterprises; foreign direct investment; Brazil; industrial policy; investment promotion; innovation; export promotion.

JEL Classification: F2; F5; F6; L2; O3.

\footnotetext{
* For comments on earlier drafts, I thank Eduardo Silva, Evelyne Huber, and respondents at the Latin American Studies Association (LASA) conference in Rio de Janeiro, 2009.

** Assistant Professor, Department of Political Science, Tulane University, New Orleans, LA, e-mail: pegan1@tulane.edu. Submetido: 28/Maio/2013; Aprovado: 24/Abril/2014.
} 


\section{INTRODUCTION}

Brazil has enjoyed remarkable success in attracting Foreign Direct Investment (FDI), especially since the mid-1990s. Investments by multinational firms have been hailed by Brazilian policymakers and others as evidence of Brazil's status as an emerging economic superpower. Certainly they do represent a kind of validation of Brazil's robust economic record. However, upon closer inspection much of this FDI has not been as beneficial for Brazil's economic development as initially hoped. Many of the investments have been market-seeking, with little in the way of spillovers. Market-seeking FDI, by definition, identifies domestic consumption potential and then sells finished products and/or services in local markets. While there is nothing intrinsically wrong with market-seeking FDI, it usually ranks below other types of FDI as a form of investment likely to lead to developmental outcomes in the host economy. Bodies such as The Economic Commission for Latin America and the Caribbean (ECLAC) have long championed innovation- and export-intensive FDI, among other types, as more desirable variants of investment, and have lamented Latin America's tendency to attract mostly market-seeking FDI. ${ }^{1}$ In a ECLAC report entitled Trade, Investment and Fragmentation of the Global Market: Is Latin America Lagging Behind?, Kosacoff et al. (2008, p. 50) point out that Latin America has not equaled other regions in moving beyond resource-based and other traditional forms of investment:

Latin America is inserted weakly in the new trends, such as the decentralization of R\&D activities or tech-based corporate services outsourcing. On the qualitative front, regardless the existence of different specialization patterns in Latin America, they are all primarily based in static comparative advantages, be it natural resources in South America or low labor costs in Central America and the Caribbean.

The inability of Brazil in particular to leverage its size and obvious economic importance into better-quality FDI in recent years is puzzling. Brazil has a relatively well-educated labor force, highlighted by its large and growing supply of PhDs. ${ }^{2}$ Brazil has the advantage of relative proximity to multinational headquarters in Europe and North America. Despite remaining infrastructure problems, it has an interstate road network and a complex and developed telecommunications system. Yet multinationals do not look to Brazil as an export platform the way they look to China. Firms do not construct call centers, outsource business processes, or conduct R\&D in Brazil at the rate they do in India.

\footnotetext{
${ }^{1}$ See the annual series Foreign Investment in Latin America and the Caribbean (ECLAC, 2004, 2005, 2006).

${ }^{2}$ Schneider (2013) notes a recent finding that Brazil is producing more than 10,000 new PhDs per year, but fewer engineers compared to countries such as China and South Korea.
} 
In this analysis, I adopt an institutionalist perspective to explain dominant investment models in Brazil during the period of 1990 to 2010, arguing that the characteristics of (1) investment promotion policies and (2) bureaucracies charged with investment promotion interact to influence investment profiles. On the policy side, I argue that Brazil's investment promotion policies affected the quality of incoming multinational investment. Conditioned by neoliberal reform programs that delegitimized industrial policy, Brazil's investment promotion policies in the late 1990s and in the first half of the 2000s were largely passive and non-discriminating. That is, they did not consistently distinguish among different types of FDI, preferring instead to dismantle barriers to investment in a horizontal fashion consistent with market-oriented reform programs of the era. This changed somewhat when the Lula administration turned to active, discriminating investment promotion policies. However, The Lula administration's efforts were often undercut by institutional rigidities, in effect diluting the impact of the industrial policy revival. Moreover, Brazil's late conversion to active, discriminating investment promotion strategies put the country at a strategic disadvantage in realizing non-traditional FDI inflows.

This article contributes to a growing institutionalist literature on the determinants of FDI patterns. While international business literature concentrates on internal firm motivations and often adopts a transaction cost approach, the characteristics of host country institutions are increasingly recognized as important drivers of FDI profiles (Dunning and Lundan, 2008). There is also a small literature on post-Washington Consensus investment promotion policies in Latin America (Paus 2005; Gallagher and Chudnovsky, 2009). This paper adds to that growing body of work by demonstrating the importance of active, discriminating government investment promotion policies and efficient institutions in attracting highquality FDI. Policies in Brazil and Latin America as a whole increasingly reflect the realization that the benefits of FDI do not accrue automatically, but must be incentivized through efficient institutions.

The remainder of the article is divided into four sections. Second section develops a theoretic framework for state-multinational interaction, and I propose a simple model of state-firm interaction. Third section presents data on firm investment models in Brazil since the 1990s, concentrating on two activities often associated with higher-quality FDI: innovation and exporting. Fourth section presents an analysis of Brazilian investment promotion policies since the 1990s, along with analysis of the governmental bodies responsible for promoting investment. I connect the largely market-oriented forms of investment with passive investment promotion and weakly coordinated institutions, and later emergence of higher-quality FDI with more discriminating investment promotion policies. In the last section, I summarize the main arguments. 


\section{DOMESTIC INSTITUTIONS AND FOREIGN DIRECT INVESTMENT}

Institutionalist analysis is often applied to patterns of state interaction with multinational firms. ${ }^{3}$ Domestic institutions are important determinants of successful multinational-intensive development strategies, as state institutions are the primary interlocutors between governments and foreign firms. Societal forces are important determinants of investment policy and industrial policy in general, but they do not account for the full complexity of the relationship between multinational firms and host countries. The role of state initiative (policies), and the bureaucracies through which these initiatives are refracted, must be considered. As the state functions as the gatekeeper between societal interests and multinational firms, scholars must pay close attention the character of investment promotion institutions.

I argue that states do have policy levers to pull in their interactions with firms. Of course, there are a large number of factors that determine the investment activity of multinational firms in developing countries, many of which are outside the control of the host country government. Because of this, isolating those institutional and policy variables which influence the character of multinational investment is often difficult. Figure 1 is a graphical representation of the general incentive structure facing multinational firms, and divides host country policies from other factors that influence multinational investment decisions.

Figure 1: A Model of State Agency and Firm Incentives for Investment

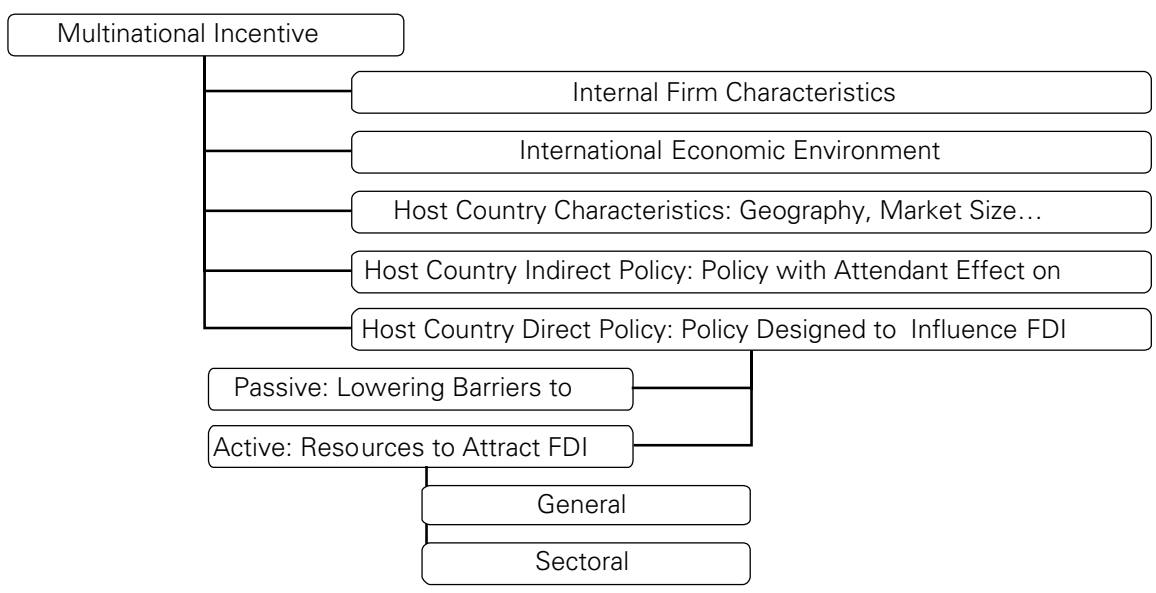

The two bottom categories of the multinational incentive structure displayed in Figure 1 are the more proximate concerns of this paper. Firms may respond to ev-

\footnotetext{
${ }^{3}$ In this paper, I use the more limited definition of institutions applied by Hall and Taylor: "organizations and the rules or conventions promulgated by formal organization" (1996, p. 938).
} 
erything from legislation on intellectual property rights to changes in exchange rate regimes to tariff reductions on inputs. Therefore it is useful to analytically separate types of investment policy. A common distinction in policy circles is between direct and indirect measures, though the exact terminology may vary. This refers to those measures which are specifically designed to change the behavior of firms in country or attract new entrants (direct) and those policies that are designed for other purposes but may have concomitant impact on multinational investment (indirect). The stabilization of the domestic currency in Brazil in 1994 is an example of indirect policy. Though the objectives of this initiative went far beyond the bounds of international investment, it had a profound positive impact on investment flows.

Direct investment promotion policy is most important for this work. Direct policy is that which is designed specifically to influence the volume and character of incoming FDI. Potential host countries may create Investment Promotion Agencies (IPAs), which have been shown to influence aggregate investment flows under certain conditions (Morriset, 2003). States might also ease restrictions on foreign capital. State direct action may involve committing resources to investment attraction (active), or may involve reducing barriers to entry (passive). Developing countries have increasingly been devoting resources to the active recruitment of FDI, as evidenced by the increasing number of IPAs worldwide. An example of direct, active policy would be a funding initiative designed to increase linkages between multinational auto parts firms and academic institutions in the host country, in order to encourage technological spillovers.

The last distinction relates to the scope of the policy measure: sectoral policy privileges a certain sector or sectors, while general active policy is policy designed to encourage investment across the board. Many developing country governments have recently adopted hierarchical models of FDI promotion, distinguishing among different forms of investment and targeting those deemed more likely to contribute to development. Numerous recent studies of FDI in developing countries have concluded that certain forms of investment are more beneficial for development than others and that the benefits of FDI are not automatic (Kumar, 2002; Nelson, 2009). Yet countries differ markedly in the degree of sectoral discrimination they apply to active investment promotion.

\section{THE QUALITY OF FDI IN BRAZIL SINCE THE 1990S: SOME EMPIRICS}

The mid-1990s witnessed a dramatic increase in FDI in Brazil. FDI inflows represented just 0.57 per cent of GDP in 1995. By 2000, they represented 5.08 per cent of GDP. ${ }^{4}$ The reasons for this increase in investment are well known. Save for a brief but substantial devaluation episode in 1999, the value of the currency was remarkably stable. The economic reform programs of the 1990s included measures generally

\footnotetext{
${ }^{4}$ Data from the Central Bank of Brazil, available at www.bancocentral.gov.br.
} 
viewed favorably by multinational firms, such as amendments to the constitution in 1995 which allowed foreign investment in sectors of the economy that had previously been off limits. The privatization reform programs of the 1990s put a number of lucrative sectors of the economy into foreign hands, mostly in services. ${ }^{5}$ A number of new foreign automobile manufacturers entered Brazil in this decade. In addition, the robust growth of the Brazilian economy since the 1990s created a larger consumer class, and multinationals have been eager to sell to this growing market.

\section{Innovation-intensive FDI}

Among the various forms FDI can take in developing countries, technology-intensive FDI or innovation-intensive FDI is generally considered to be more advantageous for development. There are many reasons for this. In some sectors, most notably the information technology (IT) sector, the technological frontier is so distant that foreign firms represent one of the only sources of innovation spillovers available to developing countries. The transfer of innovative products or practices to domestic partner firms, or to other local agents, is a potential benefit of innovation-intensive investment. Innovative firms may further integrate with the international marketplace and strengthen competitiveness. Multinationals may aid in the development of domestic clusters focused on innovation, and may reverse "brain drain" pressures in developing countries. Innovative multinationals may also bring additional supporting FDI.

In Brazil, the degree to which multinationals engage in innovative activities is a matter of some debate. Arbix (2005) found that national firms were more innovative than multinational firms, with national firms investing 80 per cent more in R\&D than transnational affiliates with similar size and characteristics. De Negri and Turchi (2007) echo these findings, arguing that transnational corporation subsidiaries in Brazil spend 62 per cent less R\&D than national firms. However, other studies find different dynamics. Braga and Willmore (1991), in their logit analysis of 4,342 firms in Brazil, find that foreign ownership increases the likelihood that a firm will engage in research and development.

This analysis finds support for the pessimists. Brazil has not been able to attract as much innovation-intensive FDI as its BRIC competitors. In a 2004 survey of 104 senior executives of large multinational corporations conducted by the Economist Intelligence Unit, respondents were asked in which countries they planned to spend the most on R\&D in the next three years. Brazil was one of the top three destinations in 11 per cent of executive responses. India was one of the top three for 28 per cent, and 39 per cent indicated China was one of their top three locations for R\&D spending (EIU, 2004). Table 1 presents data from the US Bureau of Economic Analysis that charts the financial and operating activities of US investment abroad. This limits the data to American firms only. However, the United States is

\footnotetext{
${ }^{5}$ Services accounted for 80.2 per cent of total FDI flows between 1996 and 2000, and 52.9 per cent of flows between 2001 and 2004. The dominance of services in total FDI continued after the liberalization programs. FDI inflows in services averaged 49.52 per cent of total FDI flows between 2003 and 2008, while the manufacturing sectors attracted 37.66 per cent over the same period (ECLAC, 2009, p. 50).
} 
Latin America's biggest single investor. In Table 1 the R\&D expenditures of majority-owned American firms in 2007 are contrasted with similar efforts of majority-owned American firms around the world. In this Table I adopt the approach used by Hiratuka (2009, pp. 33-50), in which the share of American R\&D activity displayed by a given country is contrasted with that country's share of overall value added (in ratio form). ${ }^{6}$ The last column in Table 1 displays these data. A higher ratio value demonstrates that a country exhibits more local R\&D by American firms than its share of global American value-added would suggest. Brazil scores better than other Latin American countries on this measure, but lags behind countries such as China, India, and South Korea. Moreover, American firms in Brazil do not exhibit large R\&D expenditures (as a percentage of value added) compared to American firms in these other countries.

Table 1: R\&D Expenditures of Majority-Owned Foreign Affiliates of US Multinationals in 2007, Selected Countries

\begin{tabular}{|c|c|c|c|c|}
\hline & $\begin{array}{l}R \& D \text { expenditures } \\
\text { as a percentage of } \\
\text { value-added }\end{array}$ & $\begin{array}{c}\text { Share in } \\
\text { total R\&D } \\
\text { expenditures } \\
\text { of US } \\
\text { multinationals }\end{array}$ & $\begin{array}{l}\text { Share in total } \\
\text { value-added of US } \\
\text { multinationals }\end{array}$ & $\begin{array}{l}\text { Share in } R \& D / \\
\text { Share in } \\
\text { value-added }\end{array}$ \\
\hline Brazil & 1.91 & 1.76 & 2.83 & 0.62 \\
\hline Chile & 0.39 & 0.14 & 1.11 & 0.13 \\
\hline Costa Rica & 0.54 & 0.02 & 0.12 & 0.18 \\
\hline Mexico & 0.99 & 0.88 & 2.74 & 0.32 \\
\hline China & 5.47 & 3.41 & 1.91 & 1.78 \\
\hline Hong Kong & 0.73 & 0.27 & 1.13 & 0.24 \\
\hline India & 5.18 & 1.11 & 0.66 & 1.68 \\
\hline $\begin{array}{l}\text { Korea, } \\
\text { Republic of }\end{array}$ & 7.64 & 2.69 & 1.09 & 2.48 \\
\hline Russia & 1.43 & 0.29 & 0.62 & 0.46 \\
\hline Singapore & 2.82 & 1.59 & 1.74 & 0.92 \\
\hline Taiwan & 1.48 & 0.28 & 0.59 & 0.48 \\
\hline
\end{tabular}

Sources: Bureau of Economic Analysis, financial and operating database for US multinational investment. Available at http://www.bea.gov/international/di1usdop.htm.

\footnotetext{
${ }^{6}$ Hiratuka (2009) used sales data, but I employ value-added. According to the BEA financial and operating database, value-added signifies the portion of the goods and services sold or added to inventory or fixed investment by a firm that reflects the production of the firm itself. Compared to sales, value-added is a preferable measure of production when available because it "indicates the extent to which a firm's sales result from its own production rather than from production that originates elsewhere, whereas sales data do not distinguish between these two sources of production" (BEA financial and operating database, available at http://www.bea.gov/international/di1usdop.htm).
} 
Table 2 compares the prominence of R\&D efforts among all foreign firms (not only American) in four Latin American countries, from 2003 to 2009. These data, gathered from ECLAC, aggregate announced multinational investments over seven years, from 2003 to 2009. The data used to construct this indicator divide FDI $\mathrm{R} \& \mathrm{D}$ projects by country. The indicator simply relays the percentage of investments with R\&D components, as indicated by announced $R \& D$ projects, and compares this with the country's GDP weight in the Latin American region. According to this aggregate indicator, Costa Rica displays a much higher incidence of local R\&D activity than its GDP would predict. Chile scores highly on this measure as well, whereas both Brazil and Mexico exhibit less local R\&D than their economic size would predict (a score of 1 would be a perfect match between share of FDI R\&D projects and share of overall GDP for the region).

Table 2: R\&D Intensity of Total FDI in Latin America, 2003-2009

\begin{tabular}{|l|c|c|c|c|}
\hline & Brazil & Chile & $\begin{array}{c}\text { Costa } \\
\text { Rica }\end{array}$ & Mexico \\
\hline $\begin{array}{l}\text { Destination of FDI R\&D Projects, 2003-2009 } \\
\text { Ratio of percentage of R\&D projects received in each } \\
\text { country to percentage of GDP in group of countries } \\
\text { surveyed over a seven year period. }\end{array}$ & 0.913 & 1.986 & 3.786 & 0.944 \\
$\begin{array}{l}\text { Higher values indicate disproportionate share } \\
\text { of R\&D-intensive } \\
\text { FDI relative to GDP weight. }\end{array}$ & & & & \\
\hline
\end{tabular}

Sources: Raw data gathered from ECLAC, based on the Financial Times FDiMarkets database, available at http:// www.fdimarkets.com/. GDP data are from World Development Indicators. Author elaboration.

While the preceding data indicate a generally low level of innovative FDI in Brazil, especially in comparative perspective, there are of course some important exceptions. Certain sectors in Brazil, such as the bioenergy industry and other natural resource subsectors (offshore energy, for example) have seen significant R\&D investments by multinational firms. Even though the level of R\&D done by American firms in Brazil is low in comparison to places like China and India, it is growing. ${ }^{7}$ Yet these recent advances have not brought Brazil to its potential as a R\&D destination.

\section{Export-oriented FDI}

Export-oriented FDI is another form of investment that can potentially bring benefits to host countries. It can increase the competitiveness of a country's exports in world markets. When a multinational firm and its domestic suppliers/partners are exposed to international competition, the discipline of the international market should force firms to develop new skills and products in order to survive. Increased competitiveness generates more foreign exchange for the host country, which can

\footnotetext{
${ }^{7}$ In 2006, US majority-owned corporations invested US\$ 571 million in R\&D operations in Brazil, 185 per cent more than in 2001 (Cruz and Chaimovich, 2010).
} 
then be transformed into needed imports. Large export-capable multinational enterprises may enjoy economies of scale, leading to more efficient use of resources.

The trade balance of multinationals in Brazil has become decidedly negative in recent years, though this is truer for some sectors than for others. Partly this is the result of a strong currency after 1995, but it is also a result of multinationals' predominantly market-seeking strategies. Most studies on the export behavior of multinationals in Brazil have highlighted the growing trade deficits of these firms. One of the earliest systematic studies of multinational investment profiles in Latin America was conducted by Newfarmer (1979), who argued that multinationals in Latin America had higher import propensities than local firms. Baumann (1993, pp. 487-512) found that intrafirm trade had increased by 16.5 per cent per year, on average, from 1980 to 1990, as firms sought to establish productive capacity in order to sell to Brazil's population. Nonnenberg (2003), using data from the state of São Paulo, found that foreign firms increased their imported inputs from 1994 to 1996 at a greater rate than national firms, and that this was especially true for technology-intensive sectors. Laplane and Sarti (1999), in a sample of 74 firms, found that while exports had increased 91 per cent between 1989 and 1997, imports had increased 395 per cent in the same period.

In an extensive study of the trade balances of multinationals, Corrêa de Lacerda (2003) utilized data from two censuses of foreign capital (in 1995 and 2000) to argue that imports of multinationals had grown more quickly during that period than exports from the same firms. While both imports and exports exhibited substantial growth between 1995 and 2000, imports of multinational firms increased 63 per cent whereas exports increased by 53 per cent. This trend was driven by firms with majority foreign participation (ownership). This suggests that majority foreign control brings with it a propensity for a negative trade balance. These dynamics were largely limited to manufacturing and service sectors. Natural resourceseeking multinationals were export-intensive. This dynamic, whereby positive trade balances exist for multinationals in natural resource sectors but firms in higher value-added sectors are import-intensive, remains a prominent feature of FDI in Brazil. According to a recent analysis of the Brazilian IT manufacturing sector, now dominated by multinationals, the trade deficit grew from US\$ 3.5 billion in 2003 to US\$ 12.1 billion in 2009 (Gutierrez, 2010, pp. 5-48).

Nowhere is this more evident than in Brazil's main export processing zone (EPZ) for consumer electronics, the Free Zone of Manaus (ZFM). The ZFM has been operating since 1957, and through its unique tax status the Brazilian government has succeeded in attracting a number of contract manufacturers and even a few global IT flagship companies to a remote region. However, the zone was originally intended to serve as an important export base. This goal was eventually abandoned, due to uncontrolled smuggling and firms' desires to access the lucrative internal market (McIntyre et al.,1996). Since 1990, the zone has demonstrated large trade deficits. Table 3 demonstrates the consistent growth of foreign inputs in the ZFM since 1990, along with the low proportion of foreign sales over the same time period. The ZFM has been operating for some time now as essentially an assembly 
platform for imported inputs. Most of the high value-added components, such as semiconductors, are imported. The zone is, in effect, an EPZ without the "E".

Table 3: Import and Export Patterns for the Consumer Electronics and IT Industry in the Free Zone of Manaus, 1990 to 2009

\begin{tabular}{|c|c|c|c|c|c|c|}
\hline & \multicolumn{3}{|c|}{ Source of Inputs (percentage) } & \multicolumn{3}{|c|}{ Destination of Production (percentage) } \\
\hline Year & $\begin{array}{l}\text { Regional } \\
\text { Inputs }\end{array}$ & $\begin{array}{c}\text { National } \\
\text { Inputs }\end{array}$ & $\begin{array}{l}\text { Foreign } \\
\text { Inputs }\end{array}$ & $\begin{array}{c}\text { Regional } \\
\text { Sales }\end{array}$ & $\begin{array}{c}\text { National } \\
\text { Sales }\end{array}$ & Foreign Sales \\
\hline 1990 & 41.16 & 42.34 & 16.5 & 20.16 & 79.71 & 0.13 \\
\hline 1991 & 38.69 & 36.77 & 24.54 & 22.06 & 77.76 & 0.18 \\
\hline 1992 & 33.62 & 31.73 & 34.64 & 16.77 & 82.83 & 0.4 \\
\hline 1993 & 22.82 & 33.08 & 44.1 & 13.72 & 85.94 & 0.34 \\
\hline 1994 & 24.75 & 27 & 48.25 & 15.16 & 84.47 & 0.38 \\
\hline 1995 & 24.69 & 24.03 & 51.28 & 17.88 & 81.85 & 0.26 \\
\hline 1996 & 27.42 & 10.04 & 62.54 & 16.91 & 82.94 & 0.15 \\
\hline 1997 & 21.31 & 20.08 & 58.61 & 13.12 & 86.69 & 0.19 \\
\hline 1998 & 19.39 & 24.97 & 55.64 & 11.05 & 88.14 & 0.81 \\
\hline 1999 & 16.1 & 19.87 & 64.03 & 11.31 & 85.41 & 3.28 \\
\hline 2000 & 19.78 & 16.66 & 63.56 & 14.99 & 79.84 & 5.17 \\
\hline 2001 & 21.95 & 15.06 & 62.99 & 15.53 & 74.86 & 9.62 \\
\hline 2002 & 25.27 & 11.99 & 62.73 & 12.08 & 72.15 & 15.77 \\
\hline 2003 & 26.13 & 7.02 & 66.85 & 12.62 & 72.41 & 14.97 \\
\hline 2004 & 31.5 & 7.37 & 61.14 & 15.08 & 77.43 & 7.49 \\
\hline 2005 & 31.66 & 7.39 & 60.95 & 16.62 & 69.74 & 13.64 \\
\hline 2006 & 30.45 & 6.1 & 63.45 & 16.55 & 76.12 & 7.33 \\
\hline 2007 & 25.15 & 7.62 & 67.23 & 12.47 & 83.84 & 3.69 \\
\hline 2008 & 19.02 & 8.61 & 72.37 & 10.5 & 84.96 & 4.55 \\
\hline 2009 & 19.13 & 6.21 & 74.66 & 8.84 & 87.61 & 3.54 \\
\hline
\end{tabular}

Source: SUFRAMA (2011).

While this section has painted a relatively bleak picture of multinationals' trade balances, it would be a mistake not to acknowledge the few bright spots. Bonelli and Pinheiro (2008) recently detailed the dramatic expansion of cell phone exports from Brazil. Exports in this sector increased from US\$ 0.3 billion in 1994 to US\$ 2.7 billion in 2006. These exports are not limited to the Mercosul market, with significant portion of exports destined for the United States. Numerous multinational cell phone makers, including Nokia and Motorola had established manufacturing facilities in prior years and recently expanded exports. Motorola in 2004 invested US\$20 million in a cellular software development facility in Jaguariúna. This expansion of cell phone production is a positive development, and constitutes an important foray into non-traditional FDI-linked exports for Brazil.

Despite these advances, the general trend is one of negative trade balances for multinationals in Brazil, and a predominance of market-seeking strategies. This dynamic is neatly captured in Figure 2, which uses data from a small-sample survey. 
The firm responses in this survey allow a comparison of export activity, measured by exports as a percentage of sales, and innovative activity, measured by $R \& D$ spending as a percentage of sales. This figure reveals a large number of firms congregated at low levels of both measures. Those firms which score highly on the export measure fail to exhibit substantial R\&D activity, and those that do spend on $R \& D$ are not particularly export-intensive. This would be consistent with the notion that export-oriented firms operating in Brazil are not conducting local innovation, and the few firms with local innovation are primarily oriented toward the domestic market. This corroborates the dominant market-seeking characteristics of FDI in Brazil and to a larger extent, Latin America.

Figure 2: R\&D and Export Propensity among 85 Multinationals Operating in Brazil, 2003

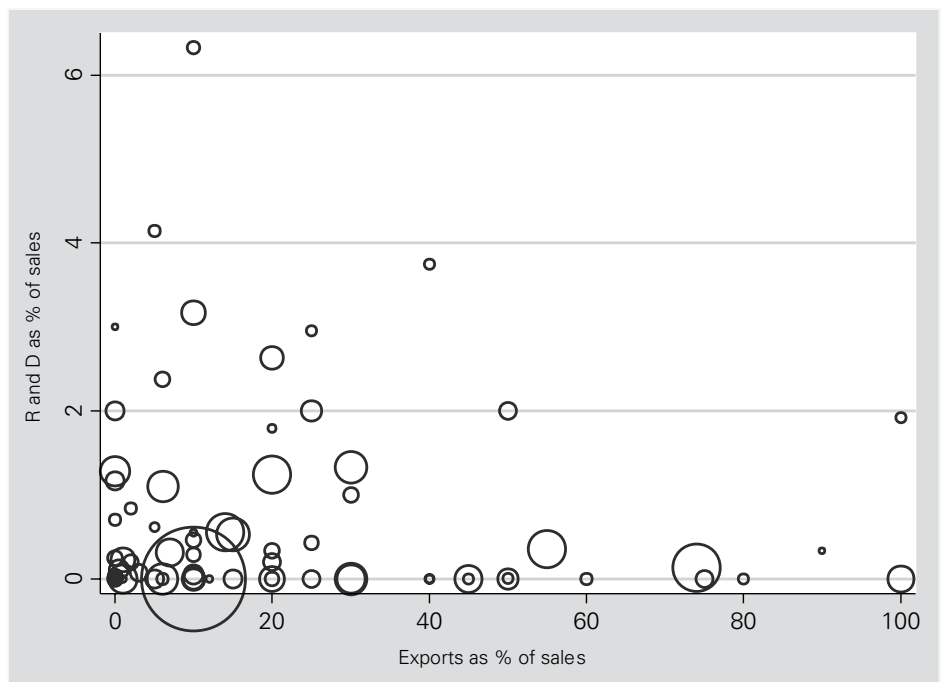

Source: Investment Climate Survey, undertaken by Sebrae, CNI, and Investe Brasil, in partnership with the World Bank. Data available at http://www.enterprisesurveys.org/. Note: Firms weighted by number of employees. Larger circles represent larger numbers of employees.

\section{THE ROLE OF INSTITUTIONS IN BRAZIL'S FDI PROFILE}

Brazil currently has a number of policies in place to incentivize multinational innovation and promote exports, but these policies are relatively recent. For much of the 1990s and into the last decade, Brazilian investment promotion policy was general and passive. This was consistent with neoliberal reform programs of the era, but put Brazil at a decided disadvantage in the competition for high-quality FDI. When active, discriminating policies found some support at the end of the second Cardoso administration and during the first Lula administration, Brazil had already lost ground. Adding to the challenge, policies designed to incentivize innovation- and export-intensive FDI were often channeled through a convoluted bureaucratic struc- 
ture which diluted their impact. The activist industrial policies of the Lula administration have incentivized some non-traditional FDI inflows, and Brazil's FDI profile is changing slowly. However, in many respects Brazil is lagging behind.

The lack of government support for active, sectorally discriminating measures is apparent in the brief history of the investment promotion agency Investe Brasil. This institution was operational from 2002 to 2004, but its roots extend to the late 1990s. Conceived as a "one stop shop" for foreign investors seeking information on Brazil, the body functioned with a small staff for its brief tenure. The dissolution of Investe Brasil runs counter to worldwide trends in investment promotion. The World Association of Investment Promotion Agencies, established in 1995, now counts over 100 members. Independent and well-supported investment promotion agencies are associated with higher inflows of investment (Morisset, 2003). During its tenure, the agency attracted an estimated US\$ 1.4 billion in investment projects. However, Investe Brasil represented an attempt at unified, targeted investment promotion policy of quite short duration. Its elimination was lamented at the time in the Brazilian press. ${ }^{8}$

Investe Brasil included in its mandate the specific targeting of investments which would be most beneficial to technological upgrading and promotion of exports, and its closure sent signals of discontinuity and reinforced negative perceptions of the regulatory environment in Brazil (Gregory and Arraes de Oliveira, 2005). The most proximate cause for its closure was a conflict over the funding arrangement. The Cardoso government founded Investe Brasil as a partnership between the public and private sectors, based on the notion that an investment promotion agency had to be agile and integrate the views of the private sector. As such, the agency received funding from the budgets of three different governmental ministries and 31 private groups. This funding arrangement, while innovative, quickly ran into coordination problems. The directorate of Investe Brasil spent much of its first year of existence attempting to manage the various state-level investment promotion agencies. But coordination problems also existed at the federal level, considering the large number of agencies in different ministries with some investment promotion mandate.

The turnover within these various bureaucracies was another complicating factor for the Investe Brasil mandate. Schneider (1991) has noted the peripatetic nature of Brazilian bureaucrats' careers, with individuals constantly moving among different posts at the federal and state level. Long term posts are rare, which makes the development of long term objectives and an organizational ethos more difficult. Although this itinerancy has some benefits, it also creates complications for agencies trying to establish consistency. The agencies that Investe Brasil attempted to coordinate were afflicted with this dynamic, especially during the transition from the Cardoso administration to the Lula administration. A former institutional director of Investe Brasil revealed that of 95 people within the loosely-organized investment promotion network of the fed-

\footnotetext{
${ }^{8}$ Teixeira da Costa (2004) expressed dismay at the abandonment of Investe Brasil. In another newspaper account, a number of administrators complained that none of the investment projects underway when Investe Brasil was closed were pursued, and that the efforts were basically "thrown in the trash" (Mello ,2005).
} 
eral government, 93 changed with the arrival of the Lula administration. She charged that the organization's closure was partly a result of this discontinuity. ${ }^{9}$

Through the stabilization and privatization programs of the late 1990s, the Cardoso administration adopted a largely passive approach to foreign investment. Foreign investors poured into Brazil in the 1990s for many reasons: a stable domestic currency, the domestic market of Brazil and the regional market of Mercosul, the relaxation of domestic content requirements and restrictions on foreign capital, and the political stability after the Collor impeachment. Sector-specific incentive programs were associated with the old industrial programs that Collor and eventually Cardoso sought to transcend. Indeed, industrial policy as a whole (and selective investment promotion as a subset of industrial policy) was frowned upon during this period. As one Central Bank representative put it, "industrial policy" in the late 1990 s was inappropriate language, subject to scolding. ${ }^{10}$

There were some exceptions to this general pattern in the 1990s. The 1991 Informatics Law (8248/91) established some incentives to preserve local R\&D efforts among Brazilian IT firms. However, the influx of multinational IT companies in the 1990s dramatically reduced the number of Brazilian software and hardware firms, and those that were absorbed by multinationals had many of their local design components downgraded or replaced by imports (Tigre and Botelho, 2001). At the end of the second Cardoso administration, a number of "sectoral funds" were established within the Ministry of Science and Technology (MCT). These funds were instruments designed to finance research, development, and innovation projects in Brazil. While these funds were not designed to benefit multinational corporations, multinationals could access the funds if they were willing to partner with local universities or research centers. However, the sectoral funds and the informatics law represent the only substantial policy initiatives with an indirect effect on the innovative activities of multinational firms in Brazil during the mid and late 1990s. Moreover, both the informatics law and the sectoral funds were largely intended to preserve innovation among domestic firms, not multinationals.

In terms of export promotion, the most prominent exception to the passive nature of FDI promotion in the 1990s was the package of reforms initiated in 1995 that came to be known as the Brazilian automotive regime. The automotive regime extended a combination of tariff barriers and subsidies to multinational automobile manufacturers, in order to attract new investment and encourage export. ${ }^{11} \mathrm{How}-$ ever, the plan contained no incentives for domestic innovation among multinational firms. After a period of import dominance in the early 1990s, by 1994 manufacturers began to increase automobile exports, mostly in the context of Mercosul. Much about this period suggests the automotive regime was not a result of

\footnotetext{
${ }^{9}$ Phone Interview, Denise Gregory, former Institutional Director of Investe Brasil, São Paulo, March 2008.

${ }^{10}$ Personal Interview, Central Bank Department of Financial System Surveillance and Information Management, Brasília, June 2009.

${ }^{11}$ Between 1994 and 2003, 23 new automotive assembly plants opened in Brazil (ECLAC, 2004). As a result of these new automotive investments, the automotive sector increased from 7.8 per cent of industrial GDP in 1990 to 12.1 per cent by 1997 (Rodríguez-Pose and Arbix, 2001, p. 140).
} 
autonomous investment promotion, but rather complicated bargaining within the bureaucracy and the immediate concerns of rising trade deficits (Gomez-Mera, 2007). Most export promotion policies (the automotive regime included) in the 1990s operated in a reactive fashion. The overvaluation of the Real had become a big problem for the current account already in 1995. The resulting export incentives were temporary. Corrêa de Lacerda (2003) has noted the passivity and reactive nature of policy towards multinational exports during this period. It is one thing to put out balance of payments fires from time to time, it is quite another to develop a systematic strategy for promoting multinational exports in a way that will contribute to participation in global production networks.

During the Lula administration, direct, active, and sectorally discriminating policies towards investment were more common than they had been in the 1990s. The general contours of Lula's industrial policy were outlined in two overarching policy packages, announced in 2003 and 2008 respectively: the Policy for Industry, Technology and Foreign Trade (PITCE) and the Production Development Plan (PDP). These development plans represented a return to state interventionism while at the same time acknowledging the parameters set by liberal reforms. The PITCE was accompanied by two important legislative initiatives: the Lei de Inovação (or "Innovation Law" 10,973/2004) and the Lei do Bem (or "Law of the Public Good" 11,196/2005). The first of these two laws was particularly important in that it encouraged public research institutions to cooperate with private companies, and allowed the sharing of lab space and the possibility of remuneration for public research institutions engaged in these cooperative relationships. The Lei do Bem added a number of concrete tax and other incentives to the general parameters of the innovation law, focusing in particular on the IT sector. Of particular note are the incentives that offered tax deductions on industrial products used for $R \& D$, the accelerated depreciation of capital goods used for innovative purposes, the accelerated amortization of intangible goods used in innovation, and partial state compensation of researchers with appropriate qualifications employed by firms. The fiscal incentives provided by the Lei do Bem are increasingly utilized by firms. In 2006, the first year the incentives were available to firms, 130 firms took advantage of the incentives. The incentives granted that year totaled approximately R $\$$ 230 million. In 2007, the number of benefitted enterprises increased to 321, and the incentives totaled R $\$ 884$ million (ANPEI, 2009, pp.32-6). The Lei do Bem also established a special regime for the acquisition of capital goods for exporting companies, known as RECAP. This regime allowed companies that export 70 per cent or more of sales to purchase or import capital goods with the suspension of the PIS and Cofins taxes. Another tax regime, the special regime for exports of technology services (REPES) was made available for firms exporting technology services, which similarly suspended these same taxes. ${ }^{12}$ Both the REPES and RECAP measures are available to multinational firms. In addition to these measures, recent strengthening of the incentives in the informatics law encouraged a number of

\footnotetext{
12 Brazilian Investment Information Network (RENAI), summary of laws and incentives impacting multinational firms in Brazil.
} 
other IT firms to establish local R\&D centers. Among these were Ericsson's R\&D center in Indaiatuba (inaugurated in 2001), and Siemens' and Nokia's R\&D centers in Manaus (Bonelli and Pinheiro, 2008; Gutierrez and Crossetti, 2003).

The Lula administration's legal changes were accompanied by a new set of agencies that would carry out the mandate of the PITCE. At the end of 2004, the federal government created two organs, the National Industrial Development Council (CNDI) and the Brazilian Industrial Development Agency (ABDI). CNDI functioned as a council of high representatives from governmental bodies and civil society, recommending initiatives to the president and responsible for the overall direction of industrial policy. The administration also strengthened another institution, The Association for the Promotion of Exports (APEX), which currently has the most direct mandate for investment promotion. APEX has existed since 1998, as part of the Brazilian support system for micro and small enterprises (SEBRAE). In 2003, APEX left SEBRAE and came under the umbrella of the Ministry for Development, Industry, and Trade (MDIC). APEX was reorganized and developed an investment promotion division. This division serves as the most direct successor to Investe Brasil, as it is charged with the active attraction of foreign investment to Brazil. However APEX as a body it is more heavily focused on Brazilian export promotion than attraction of FDI. ${ }^{13}$ APEX does not have the singular focus often found in investment promotion agencies in other countries. ${ }^{14}$

In May 2008, the government effectively replaced the PITCE with the Production Development Plan, or PDP. The PDP was largely developed within the Casa Civil. It was intended to correct some of the coordination problems that had plagued the PITCE, especially inter-ministerial conflict between the MCT and the MDIC. The Council of Economic and Social Development, the Chamber of Political Economy (under the influence of the Finance Ministry), the Chamber of the Politics of Economic Development (within the Casa Civil), and the Council Manager of the Publicprivate partnerships (PPPs) all had leadership positions within the framework of the PITCE (Suzigan and Furtado, 2006), and this had created confusion. The PDP included a focus on defined goals in terms of innovation, investment, and export expansion, which had also been missing from the more general PITCE. It retained the emphasis on priority sectors, but also began to address some of the larger manufacturing bases of the Brazilian economy. ${ }^{15}$ The PDP continued the tools used by the PITCE to incentivize innovation, including accelerated depreciation of innovationintensive capital goods and subsidies for hiring qualified personnel.

\footnotetext{
${ }^{13}$ One indication of this is that five years after the establishment of the investment promotion division within APEX, the agency's role as an investment promotion body was "less well known" (Netz, 2010).

${ }^{14}$ An editorial in Folha de São Paulo in 2007 lamented the continued lack of a central investment promotion organ, integrated with the newly ambitious industrial policies. The article also pointed out the lack of "active" strategy to attract investment (Barros, 2007).

15 This was in response to the criticism that the PITCE had targeted industries which were too underdeveloped in the Brazilian economy to affect its overall growth in any meaningful way (Suzigan and Furtado, 2006). The upward limit of individual financing packages in the Proex export program was increased to US\$20 million from US\$10 million (Ferraz, 2009).
} 
One of the most important barriers to the implementation of a discriminating, active investment promotion policy has been the sheer number of state agencies focused on investment promotion. In January 2005, the UN conference on trade and development released the results of a review of investment policy in Brazil. While the results of this survey were positive about Brazil's investment potential, the organization identified a clear lack of coordination among investment promotion bodies in Brazil. Moreover, the report called for a federal investment promotion agency that is capable of enforcing cooperation among other bodies:

A clear-cut division of tasks between the different actors is needed and can be developed so as to avoid duplication of efforts and maximize efficiency in investment promotion. (UNCTAD, 2005, p. 94).

Brazilian state institutions are "sticky", in the sense that they tend to hang around long past their prime period of effectiveness, which tends to occur shortly after their creation. Institutions are often dependent on the support of particular administrations, and after those administrations leave office the institution is left behind. Schneider documented the tendency of Brazilian administrations to carry out their development agendas through the addition of institutions, rather than the reform of existing institutions (Schneider, 1991). This both expands the state and creates a rococo bureaucratic structure, where effective implementation becomes quite difficult. There are currently a number of organizations which seek to influence FDI, and a corresponding high level of overlap and territorial behavior. In addition to agencies like ABDI and APEX, there are the investment promotion efforts of Itamaraty. The MDIC launched in 2003 its own investment information site, RENAI. Agencies such as APEX have the potential to serve as "one stop shops" for investment promotion, but this has not yet been the case.

There are a small number of agencies which do conduct active, sectorally discriminating investment promotion, and it is important to acknowledge these institutional successes. The BNDES enjoys a reputation for meritocratic staffing and independence from political pressures, and it offers low interest loans to a variety of firms, most of which are apportioned regardless of the firm's country of origin. A funding line created in 2008, known as the Technological Innovation fund, was designed to support innovation projects of over R 11 million. A second funding line, known as Capital Inovador, was created in 2006 and has a maximum support amount of R $\$ 200$ million, renewable up to 12 years (ANPEI, 2009, pp. 45-6). The BNDES has another technology fund, known as FUNTEC, which does not target firms directly but instead funds research centers that may partner with multinational firms. The resources for export promotion have been growing as well. The BNDES disbursed US\$ 2.1 billion in export financing in 1999. By 2008, the bank disbursed US\$ 6.6 billion. ${ }^{16}$ The bank also displays a discriminating approach in its lending practices; firms in high value-added sectors such as capital goods, elec-

${ }^{16}$ BNDES, financial and operating statement. Obtained during site visit, Brasília, June 2009. 
tronics, and telecommunications are more likely to receive export financing than commodities, all else equal (Catermol, 2005).

Another institution which is quite influential with foreign firms, particularly in the IT sector, is the Research and Projects Financing body (FINEP). FINEP is an institutional outgrowth of the BNDES, though now it operates within the MCT. FINEP provides grants and loans to both Brazilian universities and private corporations, without distinction based on country of origin. FINEP had existed since 1967, but its resources were greatly expanded under the Lula administration. ${ }^{17}$ Within FINEP, the Pró-Inovação program was an important source of finance for firms with sales of more than $\mathrm{R} \$ 10.5$ million. This program allowed innovative firms to access FINEP funds at lower long term interest rates. In 2008, this program was reformulated and renamed InovaBrasil. This program combines credit lines with other instruments such as vouchers, which can be used by firms to contract domestic research partners. At the end of 2008, the median value of support per firm was R \$ 31 million, whereas in 2005 the Pró-Inovação program had a median value of only R \$ 12.8 million (ANPEI, 2009).

Beyond BNDES and FINEP, effective investment promotion institutions within the Brazilian bureaucracy are few. There are a number of other institutions which prioritize and support innovation among multinational firms, but none have the resources or autonomy of these two organizations. Moreover, it is unclear whether a "pockets of efficiency" strategy, whether intentional or by default, will lead to a cohesive strategy to incorporate high-quality FDI into ambitious industrial policies.

\section{CONCLUSIONS}

Considering Brazil's economic weight and potential, its educational system and developing infrastructure, and various other advantages, the relative lack of higher-quality FDI is puzzling. This article proposes a domestic institutional explanation for dominant investment profiles of multinational firms in Brazil since 1995. The characteristics of Brazilian investment promotion policies and those of bureaucracies charged with their implementation help to explain the relative lack of export-oriented and innovation-intensive FDI since liberalization. Brazilian administrations initially opted for passive, general forms of investment promotion. At the end of the second Cardoso administration and throughout the Lula years Brazil turned gradually toward active, discriminating investment promotion and realized some successes in limited sectors. However, when active, discriminating policies did emerge, they were often undercut by problems with bureaucratic consistency and coordination. Though a small number of bureaucracies, such as BNDES and FINEP, have managed to attract and incentivize some high-quality FDI while operating independently, Brazil did not exhibit a systematic and unified strategy for attracting non-traditional FDI. This often contributed to a more-or-less natural

\footnotetext{
${ }^{17}$ Funding for FINEP increased tenfold between the Cardoso and Lula administrations. Phone Interview, Dr. Eduardo Costa, FINEP Director of Innovation, Rio de Janeiro, May 2008.
} 
state for incoming FDI, which often combines market-seeking strategies with import dependence (aside from natural resources) and low spillover potential.

More broadly, this analysis suggests that the types of policies adopted by host countries can have an important influence on the investment profiles of multinational firms, and on the quality of overall FDI. Moreover, the bureaucracies through which these policies are channeled may enable the host government to employ leverage on firms. Brazil was a relative latecomer to activist investment promotion strategies. For recently changed policies to truly make an impact, the bureaucracies which implement them will need reform as well. Proactive policies towards FDI are more in evidence, but these policies can only be effective inasmuch as their institutional channels work in a cohesive fashion. Consistent with recent works that recognize the trend of outward-oriented industrial policy in Latin America, this analysis advances the notion that domestic institutions can have a significant impact on the form and evolution of FDI. Active investment promotion policies, when channeled through efficient institutions, represent a ready source of competitive advantage for governments as they seek to attract high-quality foreign investment.

\section{REFERENCES}

ANPEI - Associação Nacional de Pesquisa e Desenvolvimento das Empresas Inovadoras (2009) Os novos instrumentos de apoio à inovação: uma avaliação inicial. Brasília: Centro de Gestão e Estudos Estratégicos.

ARBIX, G. (2005) "Inovações, padrões tecnológicos e desempenho das firmas industriais brasileiras. Estudos e Pesquisas, v.96.

BARROS, G. (2007) "Brasil quer aproveitar enxurrada de dólares que entra para investimentos”. Folha de São Paulo. 24 July, 2007.

BAUMANN, R. (1993) “Uma avaliação das exportações intrafirma do Brasil: 1980 e 1990”. Pesquisa e Planejamento Econômico, v.23, n.3, p. 487-512, 1993.

BONELLI, R.; PINHEIRO, A. (2008) "New export activities in Brazil: comparative advantage, policy or self-discovery?” Research network working paper R-551. Washington: Inter-American Development Bank.

BRAGA, H.; WILLMORE, L. (1991) "Technological imports and technological effort: an analysis of their determinants in Brazilian firms", The Journal of Industrial Economics, v.39, n.4, p.421-432,

CATERMOL, F. (2005) "BNDES-exim: 15 anos de apoio às exportações brasileiras", Revisto do BNDES, v.12, n.24, p.3-30.

CORREAA DE LACERDA, A. (2003) Globalização e inserção externa da economia brasileira: política econômica, investimentos diretos estrangeiros e comércio exterior na década de 1990. Campinas: $\mathrm{PhD}$ dissertation.

CRUZ, C.; CHAIMOVICH, H. (2010) “Brazil”, Unesco Science Report. Paris: Unesco.

DE NEGRI, J.; TURCHI, LM. (2007) Technological Innovation in Brazilian and Argentine Firms. Brasília: IPEA.

DUNNING, J.; LUNDAN, S. (2008) "Institutions and the OLI paradigm of the multinational enterprise", Asia Pacific Journal of Management, v.25, p.573-593.

ECLAC. Foreign Investment in Latin America and the Caribbean. Santiago: ECLAC, various years.

EIU. (2004) "Scattering the seeds of invention: the globalisation of research and development". London: Economist Intelligence Unit, 2004.

FERRAZ, M. (2009) "Retomando o debate: a nova política industrial do governo Lula”, Planejamento e Políticas Públicas, v.32, p.227-263.

GALLAGHER, K; CHUDNOVSKY, D., eds. (2009) Rethinking foreign investment for sustainable development: lessons from Latin America. New York: Anthem. 
GOMEZ-MERA, L. (2007) "Macroeconomic concerns and intrastate bargains: explaining illiberal policies in Brazil's automobile sector", Latin American Politics and Society, v.49, n.1, p.113-140.

GREGORY, D.; ARRAES DE OLIVEIRA, M. (2005) "O desenvolvimento de ambiente favorável no Brasil para a atração de investimento estrangeiro direto”, CEBRI Working Paper. Rio de Janeiro: CEBRI.

GUTIERREZ, R. "Complexo eletrônico: lei de informática e competitividade”, BNDES Setorial, v.31, p.5-48.

GUTIERREZ, R.; CROSSETTI, P. (2003) “A indústria de telequipamentos no Brasil: evolução recente e perspectivas”, BNDES Setorial, v.18, p.23-90.

HALL, P.; TAYLOR, R. (1996) "Political science and the three new institutionalisms", Political Studies, v.44, n.5, p.936-957.

HIRATUKA, C. (2009) "Islands of possibility: MNCs and economic development in Brazil", in Gallagher, K.; Chudnovsky, D. (eds.), Rethinking Foreign Investment for Sustainable Development: Lessons from Latin America. New York: Anthem.

KOSACOFF, B.; LÓPEZ, A.; PEDRAZZOLI, M. (2008) Trade, Investment and fragmentation of the Global Market: is Latin America Lagging Behind? Santiago: CEPAL Estudios y perspectivas.

KUMAR, N. (2002) Globalization and the Quality of Foreign Direct Investment. New Delhi: Oxford University Press.

LAPLANE, M.; SARTI, F. (1999) "Investimento direto estrangeiro e o impacto na balança comercial nos anos 90", Texto para discussão 629. Rio de Janeiro: IPEA.

MCINTYRE, J.; NARULA, R.; TREVINO, L. (1996) "The role of export processing zones for host countries and multinationals: a mutually beneficial relationship?”, International Trade Journal, v. 10, n.4, p.435-466.

MELLO, P.C. (2005) “Apex-Brasil inaugura estrutura visando trazer projetos estrangeiros para o país; nova unidade para atrair investimentos”.. Jornal do Comercio. 31 January, 2005.

MORISSET, J. (2003) "Does a country need a promotion agency to attract foreign direct investment? a small analytical model applied to 58 countrie", World Bank policy research working paper 3028. Washington: Foreign Investment Advisory Service.

NELSON, R. (2009) Harnessing Globalization: The Promotion of Nontraditional Foreign Direct Investment in Latin America. State College: Penn State University Press.

NETZ, C. (2010) "Brasil entra no radar dos investimentos tecnológicos", O Estado de São Paulo. 15 July, 2010.

NEWFARMER, R. (1979) "TNC takeovers in Brazil: the uneven distribution of benefits in the market for firms", World Development, v.7, n.1, p.25-43.

NONNENBERG, M. (2003) "Determinantes dos investimentos externos e impactos das empresas multinacionais no Brasil: as décadas de 1970 e 1990", Texto para discussão 969. Rio de Janeiro: IPEA.

PAUS, E. (2005) Foreign Investment, Development, and Globalization: Can Costa Rica Become Ireland? New York: Palgrave-Macmillan.

RODRÍGUEZ-POSE, A.; ARBIX, G. (2001) "Strategies of waste: bidding wars in the Brazilian automobile sector”, International Journal of Urban and Regional Research, v.25, p.134-154.

SCHNEIDER, B. R. (2013) Hierarchical Capitalism: Business, Labor, and the Challenge ofEequitable Development in Latin America. New York: Cambridge University Press.

SCHNEIDER, B. R. (1991) Politics Within the State: Elite Bureaucrats and Industrial Policy in Authoritarian Brazil. Pittsburgh: University of Pittsburgh Press.

SUFRAMA (2011) Indicadores de desempenho do pólo industrial de Manaus. Manaus: Superintendência da Zona Franca de Manaus.

SUZIGAN, W.; FURTADO, J. (2006) "Política industrial e desenvolvimento", Revista de Economia Política, v.26, n.2, p. 163-185.

TEIXEIRA DA COSTA, R. (2004) “Investe Brasil tem solução”. Folha de São Paulo. 15 July, 2004.

TIGRE, P.; BOTELHO, A. (2001) "Brazil meets the global challenge: IT policy in a postliberalization environment", The Information Society, v.17, p.91-103.

UNCTAD (2005) Investment policy review of Brazil. New York: United Nations Publications. Available at http://archive.unctad.org/en/docs/iteipcmisc20051_en.pdf. 